\title{
A Critical Analysis of the Priest in the Power and the Glory by Graham Greene
}

\author{
Mathias Adandé Mehounou, Marcellin Abadame, Gerard Adounsiba \\ Benin
}

\begin{abstract}
In this article, I have sought to analyse the character of the whiskey priest in his painful and desperate quest for repentance. This quest, at first unsatisfied, urges him on fleeing away because of his rejection of the story of his rejection of the moral values which govern the world in which he lives. The story of the whiskey priest in The Power and the Glory can also be seen as the one of a man who suffers like Jesus Christ on the Way of the Cross, from human beings and from Nature. The consequence in that he goes through a moral growth in the sense that, in the end, he proves himself to be modest, compassionate in disrupting the lieutenant's habitual way of looking at the Catholic clergy.
\end{abstract}

Keywords: Martyr, Roman Catholic Church, whiskey priest, Judas, mestizo, damnation, sinful.

\section{INTRODUCTION}

The Power and the Glory tells the story of a Roman Catholic priest in the state of Tabasco in Mixico during the 1930s a time when the Mexican government, still effectively controlled by Plutarco Elias Calles, strove to suppress the Catholic Church. The persecution was especially severe in the province of Tabasco, where the atheist governor Tomàs Garrido Canabal had founded and actively encouraged fascist paramilitary groupe called the" Red-Shirts"

The main character in the story is a nameless "whiskey priest", who combines a geat power for selfdestruction with pitiful craveness, an almost painful penitence and a desperate quest for dignity.

\section{THE PRIEST'S JOURNEY WITHIN HIS SOUL}

The story starts with the arrival of the priest in a country town where Catholicism is outlawed, and then follows him on his trip through Mexico, where he trying to minister to the people as well as he can. He is also haunted by his personal demons, especially by the fact that he has fathered a child in his parish some years before. He meets the child, but is unable to feel repentant about what happened. Rather, he feels a deep love for the evil-looking and awkward little girl and decides to do everything in his power to save her from damnation. The priest's opposite player among the clericals is padre José; a priest who has been forced to renounce his faith and marry a woman (by order of the government) and lives as a state pensioner.

The power and the Glory is not only the story of a priest hunted down by a lieutenant because the state has decreed so, but also behind all that, there is a profound message which could only be grasped through a thematic analysis of the novel that would help to know the character of the priest better. Graham Greene has succeeded in showing that God is God, that is to say, he acts without partiality. Human beings would have expected to see an exemplary priest from a good mileu, but God has chosen.

In the power and the Glory, God is everywhere and belongs to everybody although some clergymen are tempted to think and behave as if God were their Thing. The whisky-priest is a case in point which cannot leave us indifferent. Just at the beginning, there is the will to escape. The very first time we see the priest is at the harbor, trying to get away. He is referred to as the stranger.

At the harbor, the stranger meets Mr. TENCH, a dentist, and they snatch a few minutes conversation. Complaining about the economic situation in the state, Mr TENCH keeps on saying: "God ora pro nobis ${ }^{1}$.

\footnotetext{
${ }^{1}$ The Power and the Glory, p. 16
} 
He was so proud and so bumptious that he secretly despised the poor. In his life, there was no room for sincerity. How it could be when it is obvious that the fear of poverty is what has brought him to priesthood? He had hated poverty like a crime and thought that if he became a priest, he would be rich and proud, loving authority? So he had worked it all out. How clever! But can a man cheat with God?

His life went on, full of hypocrisy, weakness, lust and love of authority. Out of his pulpit, he used to speak to people about poverty and misery without knowing what they actually were. He is now experiencing what poverty and suffering mean. Since he has no food, no rest, no people around himself, he feels satisfied for he can talk of suffering without hypocrisy. As he puts it himself: "It is hard for the sleek and well-feed priest to praise poverty ${ }^{2}$ ". Even his hands, plump in the old days, have now changed since "the whole world had changed".

Besides, his regged clothes as well as his hard hands help him avoid being arrested during the lieutenant's interrogations at Maria's village.

"It is an ill-wind that blows pobady any good". One thing curious is that the mysterious force never abandons him, it always holds out its hand to save him from early ordeals, preferring to wait for its time.

The priest's sufferings are not physical only, they are moral too. Thus, his last visit to Maria's village and his tête-à-tête with Brigitta; his daughter is quite moving. It brings to our mind a similar situation described by the American author Scott FITZGERALD in his short-story: Babylon Revisited. Indeed, both priest can indeed be compared to Charles Wales, the hero of Babylon Revisited. They have a daughter whom they love so much and wish they could do everything for their progeny: Brigitta on the one hand and Honoria on the other hand. Unfortunately, they can't because nature has decided otherwise.

Charlie Wales returns from Babylon (Paris) as disappointed as the priest is when he is compelled to go away, leaving Brigitta to her own destiny. He has come to the fact that one must love every soul as if it were one's own child. A new dimension is added to his obscure sense of Christian duty: the passion to protect must extend itself over a world. The immense load they call-responsibility-has now revealed itself to him. His position of incapable father makes him feel ill at ease. He avoids meeting Brigitta's gaze, since so many reproaches are fixed on it.

All happens as if the priest were being taken to task by his own conscience. As for Brigitta, she wants responsibilities to be clearly defined and punishments to fall upon guilty men. Why should she stand mockeries from pedro and the other children of the village whereas the person really responsible for "her" deplorable situation is nobody but the priest who, that day, drank Brandy and feeling alone, yielded to temptation? His dialogue with Brigitta filled him with remorse, resentment and selfreproach.

He learns a good deal too from Maria, his ex-parishioner and Brigitta's mother. But what matters, here, is not the harshness and the cruelty of Maria's works as such, but the way the priest accepts her reproaches and her insults. Now that he has become the non-respected man, he has no choice; his attitude is so humble that it is worth mentioning. Maria says to him, fiercely:

\section{"Now perhaps you'll go-go away altogether.}

You are no good anymore to anyone.

Don't you understand father?

We don't want you anymore 3 ",

But, faced with such a vehement rebuke, the priest remains calm. He merely answers:

"Oh yes, I understand. But it's not what you want or I want"

We clearly see that, once again, the mysterious force is referred to as being unique to decide: "It's not what you want or I want ${ }^{4}$ "

The priest is now quite convinced that he has to obey that force. Next is his encounter with the devout woman in prison. The words he exchanges with the woman are full of self-knowledge, humility and

\footnotetext{
${ }^{2}$ Idem: p. 71

${ }^{3}$ Ibid., p. 78

${ }^{4}$ Ibid., p. 79
} 
wisdom. He doesn't claim to be good man at all. He knows well who he is. He says, with humility: "Oh, I am not only a drunkard. I have a child 5 "

He used to be so boastful when people came to him in the past and kissed his black cotton glove. But -now, he no longer is. He is even surprised to see that his heart is now, he no longer is. He is even surprised to see that his heart is now full of companionship. Life has taught him so much. He knows for instance that there is no point in judging our fellows. More and more comprehensive, he invites the pious woman not to treat others badly, not to judge them because he knows "from experience how much beauty Satan carried sown with him when he fell".

In so behaving, the priest is following Jesus' lesson: Do not judge, so that you will not be judged" or "Love each other as I too love you ${ }^{6 "}$

His sense of uselessness is so high. He's always looking for himself. The more he thinks of all the sacrifices hostages are making to save him, the more useless he feels. He cannot keep exclaiming: "Oh God, send them someone more worthwhile to suffer for?"

We notice that between the heroic double he has dreamt of and the character whose part he is actually playing, the gap never ceases to widen: his adventure verges on the grotesque. In his past life, there was no room for love. But now in corruption, he has learnt to love people. For instance, he doesn't dislike the lieutenant although he does know he is the one commissioned to lead him to Golgotha. As the priest puts it himself, "hate is a failure of imagination".

Whenever you agree to try and imagine what God is, you are bound to feel pity for human beings. That is why the priest hates nobody and accepts his fellows without much ado. He has discovered without his knowing it, what tolerance and forgiveness are. On point is very important during his journey within the discovery of loneliness. In fact, when we see him back at the Fellows'; we cannot keep sinking with him in a tense silence, an alarming solitude.

All that is now-at the Fellows'-is the empty house and the crippled bitch. No people, no food, no hiding-place. The whole world has fled. It seems it has been decreed that he should go through every king of suffering. Thus, the priest is led to experience real tenderness and love. Faced with the little Indian wounded by the Yankee, again, he doesn't hesitate to help. He spontaneously takes off his shirt which he tears into strips in order to cur the little creature, a victim of human beings' violence. The priest has learnt now how to be human and that the secret of happiness is in service to others.

Years ago, he couldn't have done such a thing. He is ready now, at any time, to diminish himself so that God's glory be always wider and greater. The priest undergoes now a moral growth, and he looks like the son of God, the Man of sorrows. Although he told the pious woman in prison that he no longer knows how to repent and how to pray, he wearily goes down on his knees and prays after the death of the little Indian. He has learnt a lot about human dignity too. The want of food and excessive hunger lead him to dispute with a bitch over a bone.

"No food ever tasted so good", he appreciates. Such an ironic though coming from the priest's mouth reminds us of Gloucester in King Lear. After he is blinded, Gloucester says later:

"Full of its seen,

Our means secure us and our mere defects

Prove our commodities9".

It is true that we only appreciate things conveniently when we are deprived of them. After the priest's journey in the company of the Indian woman, he notices a sudden change in his life and manners. The love of authority is back in all his sayings. When he realises such a change in his manners, he feels ashamed. And later, he makes a pitiful self-criticism that discipline is necessary to lead a meaningful life. He considers himself as undisciplined. Having given up all his duties, he is now complaining about his negligence, about his surrenders: feast days and days of abstinence.

\footnotetext{
${ }^{5}$ Ibid., p. 127

${ }^{6}$ St. John, 15.12

${ }^{7}$ St. John, p. 135

${ }^{8}$ St. John, p. 131

${ }^{9}$ King Lear, Act IV, Scl, p. 129
} 
But we wonder whether it is worth respecting fast days just for the pleasure of pleasure of doing it. Fasting, in our opinion, must have significance. There is no point in fasting just because people do so. All is and worship Him as his heart tells him. The whisky priest seems now to get clearly Graham Greene's conception of God's omnipresence when he declares: "we are made in God's image. God is the parent, but he is also the policeman, the criminal, the priest, the maniac and the judge ${ }^{10 "}$ Each of us thus does possess the divine substance within, and all that differs is in our apparent aspect, our body.

We are all, part and parcel of the Almighty. Such a knowledge accounts for the difference among human beings. Such a difference is necessary and, when it is understood, it can only appeal to our tolerance and no forgiveness, there will not be any religion. Such a tolerance helps us accept our fellows and connive at by human beings and tries to stick to their qualities only. This enables him to recognize that the lieutenant is not such a bad man.

As a matter of fact, he is driven by an obsessive hatred for the Catholic Church, he will stop at nothing to apprehend and execute the priest, who, he believes, is the last remaining clergyman in the state. The lieutenant is a principled, disciplined man with a strong sense of justice. He is committed to political ideals that he thinks will help the poor and create equality and lolerance in the state. Unfortunately, he oftentimes allows his focus on his noble goal. The most striking example of this is his decision to round up hostages and execute people if the villagers lie to him about the priest's whereabouts. As we see, the selection process is entirely arbitrary, hardly, just, and extremely violent. It is easy to see why the church. But even this person is capable of change. From time to time throughout the novel he shows that he is not an unkind person. After his conversation with the captured priest, he softens considerably, trying to find someone to hear the priest's confession and bringing him a bottle of brandy to quiet his fears. The political movement to which he belongs has taught him to look at people in generalised terms: that is, all priests are bad and all those working for the lieutenant's cause are good. The priest, who proves himself to be modest, intelligent and compassionate, disrupts the lieutenant's habitual way of looking at the Catholic clergy. By the end of the novel, he has accomplished his mission, but he feels a strange sense of emptiness and despondency. Without a target, his life has no meaning or sense of purpose, and Greene suggests that lingering doubts fill the lieutenant's mind troubling him about whether he has done the right by killing the priest

The more experienced you get, the more human and comprehensive you become. The priest seems now to have agreed to submit to that mysterious force rather than keep on tiring himself. The nearer he gets to the end of his mission, the more humble and honest he appears to be. With a deep and sincere humility, he confesses that he is not a pure man. He needs not hide his fear and he says: "But I'm not a saint. I'm not even a brave man ${ }^{11}$.

By then, pride is no longer in his manners. He no longer tells cants. He becomes so humble and so human because he is "defeated". As the priest says in substance in A Farewell To Arms, winners never stop acting; it is when we are defeated that we become Christian.

The priest has become another man. To see how deeply he has changed, the reader can sink with him into his soul on the eve of his death. It is so grand so high - sounding a cry of humility, all depicted by the author with such pathos: "when he woke suddenly and completely left him at the first sight of the prison yard. It was the morning of his death. He crouched on the floor with the empty brandy flash in his hand trying to remember Act of Contribution"
"O God, I am sorry and beg pardon for all my sins .... Crucified............ Worthy of thy dreadful punishments ${ }^{12}$

He was confused, his mind was on other things: it was not the good death for which one always prayed. He caught sight of his own shadow on the cell wall; it had a look of surprise and grotesque unimportance. What a fool he had been to think that he was strong enough to stay when others fled. He thought he is an impossible and useless fellow because he has done nothing for anybody. He might just as well have never lived. His parents were dead, soon he wouldn't even be a memory, perhaps

\footnotetext{
${ }^{10}$ Ibid, p. 101

${ }^{11}$ Ibid, p. 195

${ }^{12}$ Ibid., p. 210
} 
after all, he was not at the moment afraid of damnation even the fear of pain was in the background. He felt only an immense disappointment because he had to go to God empty-handed, with nothing done at all. It seemed to him, at that moment, that it would have been quite easy to have been a saint. It would only have needed a little self-restraint and a little courage. He felt like someone who has missed happiness by seconds at an appointed place. He knew now that at the end there was only one thing that counted - to be a saint". He clearly knows now that it is his duty to drink that cup of suffering just as Jesus Christ did. And then, God's will be done and the Scriptures be fulfilled.

\section{The Priest's Passion}

How then has God's will been fulfilled?

Renounce your faith, Coral explained.

He said: "It's impossible. There's no way. I am a priest.

It's out of my powers ${ }^{13}$ ".

"Father, Jesus said "if you will' take this cup of suffering away from me. Not my will, however but your will be done ${ }^{14 "}$

"If you will, take this cup of suffering away from me. Not my will, however, but your will be done

The great suffering the priest is going through can be felt in what he said. Thus, when Jesus uttered these words, he was at the peak of his Passion. One point that is striking in The Power and the Glory: is that all the Christian feasts, only Easter (the Holy Week) are referred to in the novel by the author.

"he remembered the Holy Week in the old days when a stuffed Judas was hanged from the belfry and boys made a clatter with tins and rattles as he swung out over the door. Old staid members of the congregation had sometimes raised objections: it was blasphemous. They said, to make this guy out of Our Lord's betrayer....1155

It is a very symbolic image since it is when the priest is in the presence of the mestizo-his betrayer and his Judas-that the scene of the Lord's Passion occurs to his mind. Easter, we know, consists of Christ's Passion death and Resurrection.

The story of The Power and the Glory can also be seen as the Passion, death and Resurrection of the priest. The priest's "Way of the Gross" is in fact so similar to that of Jesus Christ: suffering from human beings, from Nature and the whole carried through to the end by the half-caste, the local Judas.

The priest's "way of the Cross" is underlined through some points. Maria, the priest's ex-parishioner, is the first the priest visits Conception for the last time, the words Maria exchanges with him are not kind at all.

After a hostage has been taken in the village by the lieutenant, Maria asks the priest to go away altogether: "I know about things", she said savagely.
"I went to school". I'm not like these others-ignorant. I know you 're a bad priest. That time we were together - that wasn't all you've done. I've heard things, I can tell you. Do you think God wants you to stay and die-a whisky priest like you16?

The Priest remains silent and listens to her without anger.

Then she carries on, more heinous: "Suppose you die. You'll be a martyr, won't you? What kind of a martyr do you think you'll be? It's enough to make people mock ${ }^{17,}$.

The priest stands all those bitter words without any rancor. Is he not above all these human weaknesses? His understanding of things wanted by God is so deep that he even smiles before answering: "It's difficult. Very difficult . I wouldn't want the Church to be mocked ${ }^{1818,}$

\footnotetext{
${ }^{13}$ Ibid, p. 40

${ }^{14}$ The Gospel according to St. Luke, $(22,42)$

${ }^{15}$ Ibid, p.91

${ }^{16}$ Ibid, p. 79

${ }^{17}$ Ibid, p. 79
} 
Maria seems to have been chosen as an instrument of torture. The priest takes to brandy because he is a drunkard. But behind that fact, we think that there is the will to escape hard realities and to forget his miseries. Although, it may first appear as a resignation, it is the expression of impotence. His encounter with Brigitta, his daughter, is the second point.

The latter too makes him suffer. She watches him with "acuteness and contempt". Indeed, Brigitta symbolise the corruption of the Flesh. Peace is nowhere, neither in the state, nor in his soul or in his mind.

Before he takes leave of Maria, the priest has a "tête-à-tête" with his daughter. It is like a trial in court, the priest being the guilty person. He is conscious that Brigitta doesn't like him. That is why he is so cautious when he has to deal with her."

He moved towards her with infinite caution, as if she were an animal who distrusted him. He felt weak with longing ${ }^{19}$ ".

A few minutes later, the verdict follows on Brigitta's decision: "Don't you touch me" fform now on, Brigitta knows that she has to shift for herself rather than rely on an ever-going father. Disappointed in his attempts to redeem himself, he just contens himself with a prayer to God : "Oh God, give me any kind of death - without contrition, in a state of sin- only save this child ${ }^{20}$.

Nature also takes part in his suffering. All that surrounds him evokes forlornness. Such a dreadful atmosphere is well described by Graham Greene in the novel. With a relined language, he describes the image of vulture, for, instance, runs throughout the first part of the novel as if Graham Greene wants to make us understand that the death of the priest is imminent. It is very significant that Mr. TENCH-when he first sees the stranger-immediately realises that "death was in his mouth already".

The second image which stresses the insecurity of the priest is that of the shark, a dangerous animal. Besides, the statue of General OBREGON in said to grow green in the damp on a little brunt plaza. Such an image symbolises death.

The priest himself is portrayed in a very significant way. He is said to have a "round and hollow face charred with a three- days' beard ${ }^{21}$. That description clearly illustrates the state of destitution in which people live in the country. In fact, they are used to living in total neglect, spitting and always postponing. And this is well expressed by Mr. TENCH when he says: "A little additional pain was hardly noticeable in the huge abandonment ${ }^{2222}$

The priest's crossing of the desert is stressed when he comes back to the Fellows. Ever since his release from jail, he seems condemned to remain alone. Thus, only hunger, tiredness and solitude are now his companions. He has been walking all day on an empty stomach and food is nowhere to be found. The emptiness of the place saddens him all the more. Opportunity making the thief, he decides to wrench the bitch from its bone. He has disputed with the crippled animal over a bone and after he has won, he has thought that' no food had ever tasted so good"'. The priest is in a ridiculous and pitiful state. Later on, thirst leads him to' 'lick some water from the uneven ground; he even sucked at his soaked trousers ${ }^{23}$ ",

His solitude too becomes a real trouble for him. All around him is silent. And silence, Ad silence, prevents him from sleeping. Peace is nowhere. He has wanted peace to rest a bit, but now that he has had an apparent peace, he is afraid. If the priest needs the company of human beings, this can be understood. At the fellows, the priest uses a fine line of a poem: " for men may come and men may go, But I go on forever ${ }^{24}$ "

This is to show God's power over everything. Although the priest's solitude may appear as a warning of dangers to come, he doesn't come; he doesn't go back on his words. He sticks to his priesthood and his faith never flinches. Thus, despite his limbs hurt while in prison, he has chosen not to move for

${ }^{18}$ Ibid, p. 79

${ }^{19}$ Ibid., p. 81

${ }^{20}$ Ibid., p. 82

${ }^{21}$ Ibid., p. 79

${ }^{22}$ Ibid., p. 18

${ }^{23}$ Ibid, p. 157

${ }^{24}$ Tennyson, Poems and Plays (The Brook), Oxford University Press, p. 130 
fear that he should wake the old man who is resting on his shoulder. We clearly see that the desert crossing of the priest has not deterred him from believing in God. Rather than disheartening him, it has strengthened his confidence in the Almighty. He knows that," If God intended him to escape , he could snatch him away from in front of a firing squad ${ }^{25}$."In the novel, two characters have been very active in the priest's Passion ; the lieutenant and the half-caste.

In his work "Graham Greene", Victor Pange writes: 'the character of the priest required an opponent worthy of him. Greene has not betrayed him by opposing to him Police Lieutenant who embodies the idea of the absolute laic, perfection without God ${ }^{26}$

If the priest symbolises faith in God a certain traditional view of life the lieutenant, on the contrary, represents faith in the new revolutionary State. Thus, he uses his power and authority to attain his aim: clear the State of whatever has a link with the Church or the Church or the Church people.

Although he stands in contradiction to the priest, both of them have some common points: solitude, sense of duty, virtue. Always faithful to his sence of duty, the lieutenant catches up with the priest at the Fellows' His scent of an impeccable soldier never deceives him. Has not Coral been exacting and firm that the priest will have been arrested there? He is them compelled to hide in the barn, without light and without air. The most exciting chase takes place in his old parish, precisely in Maria's village. The suspense is so tense to the point that it makes the reader hold his breath and pray for the priest. Maria, his ex- parishioner and wife, helps him a lot. When the lieutenant, relying on his scent, checks the priest's hands, he finds them"' as hard as labourer's ". He them smells the priest's breath; fortunately, Maria made him bite a raw onion before the soldiers came. Still smelling the rat, the lieutenant resorts to Brigitta's help to get round the difficulty, but Maria's intervention spoils his plan: "'Why, the child doesn't know her own name. Ask her who her father is ${ }^{27 "}$

Once again, death has been postponed owing to God's mercy. God has not yet decreed the priest's arrest them. It is worth mentioning that the sufferings of the priest cannot be carried out without his going through the qualms of conscience and the pangs of death. This is why the half-caste will appear in his life on his way of the cross. The half-caste plays also an important role in the priest's Passion. The first time the reader gets acquainted with him is when the priest speaks to him at LA CANDELARIA, inquiring about the distance to Carmen. It is also the very first time the priest has met his "Judas " from that moment on, the mestizo follows the priest closely, joking one minute, feigning anger the minute after. He quickly elaborates a diabolic plan which helps him find out that the stranger is a priest. He pretends to be a good Christian willing to offer his services to a stranger. One moment, he says that he too is going to Carmen, the moment after, he says he wants to serve as a guide out of sheer kindness.

Another plan, more cunning, enables him to discover that the stranger is not only a priest, but the priest, the one wanted by the State. When he suggests to the priest that he should pray before they sleep at night, the priest clearly understands that he is in ten presence of a dangerous man: a man able to hand him over to the police. Afraid and ill at ease, the priest tells himself: I mustn't sleep, it's dangerous, I must watch him ${ }^{28}$ " Ideas of flight invade his brain. Unfortunately, the mestizo prevents him from doing so. Yet, the priest's attitude towards the half-caste is a striking one. Although he knows that he has sworn to betray him, he does offer his shirt to the mestizo to protect him from the cold. He even blames himself for lack of trust after his attempt to dodge the half- caste has failed. He them begs God to forgive him. Nearer to the half-caste, stands Edmund, the bastard in King Lear. The latter has elaborated a diabolicnplan to trap his half-brother Edgar. A letter is the device he uses to achieve his plan. Edmund says:

\section{If this letter speed}

And my invention thrive, Edmund the base

Shall top the legitimate

\footnotetext{
${ }^{25}$ Ibid., p. 129

${ }^{26}$ This translation is my own. The French version of the sentence is as follows: le caractère du prêtre exigeait un adversaire digne de lui. Greene ne l'a pas trahi en lui opposant le lieutenant de police qui incarne l'idée de l'absolu laïque, d'une perfection sans Dieu ». Voir Victor de PANGE, Editions Universitaires, Paris, p. 71

${ }^{27}$ Ibid., p. 76

${ }^{28}$ Ibid., p.91
} 


\section{I grow; I prosper \\ Now, gods, stand up for bastards! ${ }^{29^{\prime}}$}

A strange coincidence, as if bastards were experts in evil-doing. As paradoxical as it may seem, both of them (Edmund and the half-caste) have resorted to a letter to commit their forfeit.

Judas is said to have betrayed Jesus for money and for money too, the mestizo hand the priest over to police that is a significant similarity .there is no shame in bastard's manners when he told the priest (in prison): "What have they got you here for?

$$
\begin{aligned}
& \text { It's my job, isn't, to find you. } \\
& \text { Who's going to have the reward if they're got you already }{ }^{30,}
\end{aligned}
$$

He has no sense of human dignity .yet, the priest has accepted him as he is .he even find out some excuse -to justify the mestizo's attitude "poverty and fever and innumerable humiliation "

The priest's grandeur can easily be seen then he is so faithful to Jesus's new commandment:

"Love one another .As I have love you, so you must love one another, then every -one will know that you are my disciples ${ }^{31}$ "

Jesus gives the example of such a love by dying for human beings .He has had confidence in man .the greatest love a man can show to his fellow is to sacrifice his life for him .but it is not an easy task. yet, the priest does it, although he is crushed by the burden he carried such a heavy burden symbolises the sins of all mankind to which we must add his own sin .the cross is not only the symbol of suffering; it also symbolises the sin of all mankind to which we must add his own sin the cross is not only the symbol of suffering; it also symbolises love, love for human beings, besides, these two symbols can easily be seen through the priest's life and his way of the cross .the understanding of such a love leads, with no doubt forgiveness and tolerance. The conflict opposing the State to the elergy is nothing but the image of what takes place within a man: the fight between the temporal and the spiritual.

The outcome of such a duel depends, mostly, on personal experience. The more experienced we get, the more armed we are to face out" way of the Cross".

The priest carries this with such an unflinching courage. His calmness on the eve of this death is so startling. He sinks into his soul and does a long self- examination. His heart is full of anguish. Feeling already the pangs of death, he can't help crying,' Beating his head gently against the wall'.

To the Lieutenat's ofter to transfer him to the common cell so that he doesn't feel sad, he objects, saying : "No . I'd rather be alone. I've got plenty to do [................ So much to think about 32 ".

Solitude and calmness are what he needs to get communion with his ego, his God within. The priest reminds us of Jesus Christ praying on the Mount of Olives, on the eve of his death.

Distress and anguish come over him and he says to his disciples: Then sorrow in my heart is so great that it almost crushes me",

Them, with a deep humility, he utters: "not my will, however, but your will be done. ${ }^{33 \text { " }}$

When at last, the hour has come for the Son of God to be glorified, he prays for his "enemies" So does the priest in the novel. The way Graham Greene use the device of " the plot within the plot" makes us feel more vividly the death of the priest through that of little Juan.

If in Hamlet "The Murder of Gonzago"' helps us discover the truth, little Juan's story gives us the cue for the meaning of the priest's last murmur on "the cross". All that happens after the priest's sacrifice sheds light on the true significance of his death.

\footnotetext{
${ }^{29}$ Shakespeare, King Lear, Actl, Sc 2, p. 19

${ }^{30}$ Ibid., p. 137

${ }^{31}$ St John : 13 (34-35)

32 Ibid., p. 206

${ }^{33}$ St Luke (22-42)
} 


\section{The Significance of The Priest's Death}

The Lieutenant, who is very hard, firm and boastful at the beginning of the story, has changed gradually. At the start, the lieutenant is portrayed as the sworn enemy of the Church. But his contact with the priest has brought him a lot so far as self- discovery and knowing the mankind are concerned. Thus, he is more and more friendly. He wants to be useful to the priest. His following sentences allow the priest to get permission for confession: 'you aren't a bad fellow. If there's anything I can do for you. ${ }^{34}$

Being sensitive to the priest's situation, the lieutenant takes a big risk and brings some brandy to the prisoner. Not only has he broken the State law, but he is always ready to help: "'is there nothing more I can do for you?" he says.

The discovering of himself has awakened his meditative side. He repeats for himself what the priest told him a few minutes before: 'No pulse, no breath, no heart-beat, but it's still life-we've only got to find a name for it 35 "

He's thus regaining his true nature of a human being with a mission on earth. The Lieutenant has lost his enthusiasm once the death sentence is carried out. He is no longer boastful. He is like a man with an uneasy conscience: ' $t$ the dynamic love which used to more his trigger-finger felt flat and dead 36 "

In fact, such a sudden change does not occur by accident. It is not an isolated fact. It has a link with the execution of the priest. The Lieutenant could never have imagined himself in such a dull state after the death of his' 'enemy'. Nevertheless, his usual pride and joy have left him. As for Luis, his change is much more surprising. He used to admire the lieutenant in the past and he almost took him for a model. The glamorous figure with the revolver fascinated him most.

Little Luis even used to imitate the lieutenant in his games. But when the lieutenant has captured the priest and ordered his execution, little Luis sits with the priest and spits up to the lieutenant. Moreover, he finds now that his games in the plaza were "silly games". He feels deceived. Little Luis, in the novel, stands for the thinking man, this is the reason why is role is a symbolic one. Contrarily to his sisters who represent unthinking piety, Luis can be seen as "St Thomas " who needs to put his hands into the Man's side to believe. His critical mind leads him to measure the soldier to the priest. And then, he takes the side of the priest. It is as if God's calling has come down on him. He is now realizing that the priest is not alone; some mysterious force is with him. No sooner had he been shot dead than another priest appeared furtively. Such a sudden appearance can be regarded as the Resurrection of the hero which may be taken as a good omen: hope for the Church, better future for faith.

The coming of the new priest means the continuation of the Gospel preaching, and therefore, the revival of faith. The priest's death has not only brought Luis back to faith, but is has also roused that of pious people like Senora Jiminez and Luis's mother. Devout people take a serious risk by soaking their handkerchief in the priest's blood. Fear has-left pious people, and more than before they stick to their faith. No doubt that the priest's death has confirmed the triumph of the Church over the State decree. Even before his death, the triumph of the spiritual over the temporal was foreseeable. Thus, to Little Luis who asked the soldier if he had got the priest, the lieutenant 'tried to smile back, an odd sour grimace, without triumph or hope'"

The priest is dead for his conviction and, this brings him, to some extent, the crown of martyrdom. Without his knowing it, the priest has offered his suffering and even his life for the salvation of human beings. His martyrdom takes a deep meaning then. His death gives back to the Church its faith and its strength, and through the Church, the whole world can be saved so to speak. The priest has been used by God as his instrument for the fulfillment of noble values. By dying, the priest brings back to God the Power and the Glory. Even on the eve of his execution, he has a dreadful selfexamination. But just after all this dark thoughts, he regains courage. Fear is out of him. All this is nothing but God's miracle. The omnipresence and the boundless assistance of God occur the day the priest is executed. It is the priest himself who walks up to the shooting-place, which is not something

\footnotetext{
${ }^{34}$ Ibid., p. 206

${ }^{35}$ Ibid., p. 202

${ }^{36}$ Ibid., p. 220
} 
easy. But, thanks to God's will, he masters all his courage and he overcomes. Only God can provide such a new strength. The more abandoned the priest seems, the nearer to God he is. Thus, at the end of his terrestrial life, the priest bears no grudge against people like the Lieutenant and the half-caste. Therefore, his death can only mean the victory of noble feelings, such as love, over, over the base ones. At the end of the novel, the reader discovers the quality of the priest's character. He is at the same time individual and universal.

As an individual, his character is interesting since he has to elbow his way through an immense crowd of obstacles, difficulties and dangers. Moreover, as a universal, character, he stands for Christian faith and for suffering men. In spite of all the brutality and the cruelty soldiers impose on religious people in Mexico at that time, they stick to their faith. The pride with which the pious woman in prison speaks of her religion and of her faith is a vivid example. Besides that fact, when the priest asks an old peasant if they were expecting him, he replies:' No father. But it is five years since we have seen a priest.......it was bound to happen one day ${ }^{37}$ " People keep on hoping. Whenever they talk, they use words like "mystery" and "soul 'and" the source of life ${ }^{38}$ "

Then, faith cannot be eradicated even if people are killed. Faith remains a personal matter.

Through the whisky- priest, God has revealed himself as the winner whereas the Revolutionary State embodied in the lieutenant is the Loser.

The priest of The power and the glory has been in dire straits from the beginning to the end. He has tried all he can to avoid sufferings, but there is no way-out. So it is written, so it is one. As he puts it himself when Coral suggest he renounces his faith, he says: ' It's impossible. There's no way. I'm a priest. It's out of my power ${ }^{39}$ " In the book, behind the Police hunt, there is another hunt: that of God. God, in fact, appears to be the real Hunter, the implacable pursuer. The priest runs away, passes ,the boundary, thinking he is safe, but God is always there, may be, under the mask of the half-cast who shows him the way to sacrifice .The priest has been trying to escape God's will, but in vain: "He had tried to escape several times, but he had always been prevented... ${ }^{40}$

To act God seems to wait for the moment when man loses all hope and has nothing else to stick to. Thus, God leads the priest to accomplish nothing but His will. For instance at Mr TENCH'S, the priest has wanted to draw from his mission when a child knocks on the door. But since his wish does not matter:' he got up as though unwillingly he had been summoned to an occasion he couldn't pass by. He said sadly. it always seems to happen . Like this ${ }^{41}$ " It is only when it dawns upon him that there is no point in trying to escape the Almighty's will that he has recovered all his virtue and qualities. 'Our heart is not quiet until it rests in three ${ }^{4242 \text { '" }}$

From now on, the priest's steps are guided, little by little, perhaps to paradise. The power and the glory retraces the life of the whisky priest and chiefly his passion. The protagonist of the story, the priest is waging a war on two fronts: haunted by his sinful past, he struggles internally with deep qualms about himself, and pursued by the authorities, he words to evade capture by the police for as long as he can. The priest is not a conventional hero: he is at times cowardly, self- interested, suspicious, and pleasure- oriented. That is to say he is human. The extraordinary hardships he has endured on the run from the government for eight years have transformed him into a much more resilient and mentally strong individual, although he still carries around with him strong feeling of guilt and worthlessness. He is self-critical almost to a fault.

\section{Conclusion}

What is remarkable about Greene's depiction of the whiskey priest is that he refuses so spare us the priest's less-than-noble side, and yet also convincingly shows him overcoming his weaknesses and performing acts of great heroism. The most important single act comes near the end of the novel, when he decides to accompany the mestizo back across the border, to the state in which he is being

\footnotetext{
${ }^{37}$ Ibid., p.43

${ }^{38}$ Ibid., p. 114

${ }^{39}$ Ibid., p.40

${ }^{40}$ Ibid., p. 64

${ }^{41}$ Ibid., p. 16

${ }^{42}$ St Augustine: Confessions, I.
} 
hunted, in order to hear the confession of a dying man. The priest does not recognize the real value of his actions, nor does he fully comprehend what kind of impact he has had on people's lives. He tends to hear only from those people who have been hurt or disappointed by him in some way: Maria Brigida, the pious woman. He does not see the many people whose lives have been touched merely by coming into contacts with him or hearing about his death; Mr Tench and the boy are the two most notable examples. Because this positive influence remains hidden to him, the priest does not have a true conception of the value of his life, and therefore, remains an extremely humble man to the day of his death. He also feels that he can never be truly penitent for his sexual relationship with Maria, since it produced Brigida, his daughter, whom he loves very deeply.

\section{REFERENCES}

Baldridge, Cates. Graham Greene's Fictions: The Virtues of Extremity. Missouri: University of Missouri Press, 2000.

Duran, Leopoldo. Graham Greene: Friend and Brother, translated by EuanCameton, Harper Collins

Ernest, Hermingway. A farewell to Arms, Scribner's Magazine, 1929. Graham, Greene. The Hearts of the Matter, Penguins Editions 1948.

Graham, Greene. Brighton Rock. LONDON/ Heineman. New York: Viking, 1938

Graham, Greene. The Power and the Glory. London: Herinemann; The Labyrinthine Ways New York: Viking Press, 1940.

Hoskins, Robert. Graham Greene: An Approach to the Novels. New York: Garland Publishers, 1999.

John, Spurling, Graham Greene, Contemporary Writers, Mathuem, 1983 Kelly, Richard Michael. Graham Greene: A Study of the Short Fiction. Twayne 1992.

Paul O'Prey, A Reader's Guide to Graham Greene, Thames and Hudson, 1988 Scott, Fitzgerzld, Babylon Revisited, Scribers

Shelden, Michael, Graham Greene: The Enemy Within, ( pub. William Heinemann, 1994), Random House ed. 1995: ISBN 0-679-42883-6

Sherry, Norman (1989-2004), the life of Graham Greene: vol. 1 1904-1939,-(pub. Radom House UK, 1989), Viking ed. 1989: ISBN 0-670-81376-6. Penguin reprint 2004: Tomn, Nigel Shakespeare's Hamlet Remixed. BookSurge, 2006. Victor de Pange, Graham Greene, Classiques du XXeme siècle Editions Universitaires Whitehouse, J. C. Vertical Man: The Human Being in the Catholic Novels of Graham Greene. New York: Garland Publisshers, 1990.

\section{INTERNET SOURCES}

- http://www.whysanity.net/monos/westwing6.html

- http://members.tripod.com/-greeneland/biblio.htm

- http:/www.fantasticfiction.co.uk/g/graham-greene/

\section{AUTHORS' BIOGRAPHY}

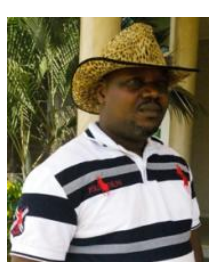

Mathias Adandé Mehounou, is Doctor to be of University of Abomey-Calavi. He is English teacher in Benin Secondaries Schools. He also teach British civilisation and Literature in University of Abomey Calavi in Benin.

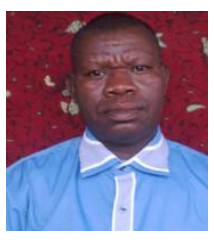

Marcellin Abadame, is Doctor to be of University of Abomey-Calavi. He is English teacher in Benin Secondaries Schools. He also teach British civilisation and Literature in University of Abomey Calavi in Benin.

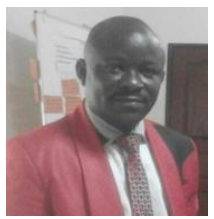

Gérard Adounsiba, is Doctor to be of University of Abomey-Calavi. He is English teacher in Benin Secondaries Schools. He also teach British civilisation and Literature in University of Abomey Calavi in Benin. 